\title{
Outsourcing in the housing sector
}

\author{
Natalia Shchepkina ${ }^{1, *}$, Maiia Kramchaninova ${ }^{2}$, and Natalia Meshkova ${ }^{3}$ \\ ${ }^{1}$ Moscow State University of Civil Engineering, 26, Yaroslavskoye Shosse, Moscow, 129337, Russia \\ ${ }^{2}$ Volodymyr Dahl East Ukrainian National University, pr. Central 59-a, Severodonetsk, 93400, \\ Ukraine \\ ${ }^{3}$ Lugansk National Agrarian University, The campus of Lugansk National Agrarian University, \\ Lugansk, 91008, Ukraine
}

\begin{abstract}
The purpose of the study is to justify the use of such a mechanism to improve the efficiency of enterprises as outsourcing, taking into account the specifics of the housing and communal services industry. The relevance is dictated by the fact that some activities are too burdensome and expensive for companies, so managers decide to use the services of contractors. Outsourcing has become an integral part of modern housing and communal services. The authors summarized the foreign experience of reforming housing and communal services and formed proposals for the implementation of outsourcing. Foreign experience of reforming of housing and communal services and the principles of management of housing stock of such countries as Germany, Poland, Great Britain, and France is analyzed. According to the carriedout analysis, some recommendations concerning the increase in the role of bodies of self-organization of the population in management of this sphere and ensuring improvement of quality of granting housing and communal services to the population are offered in the article. Advantages of the use of outsourcing in the activity of utility companies are revealed. The results of the study may be of interest to management companies in the field of housing and communal services.
\end{abstract}

\section{Introduction}

Important criterion for the evaluation of the social-and-economic situation in the country is the research of the condition of housing and communal services as one of the priority industries of the national complex, which enterprises provide various services.

The increasing importance of outsourcing in the management of modern business is evidenced by the fact that the share of foreign companies that transfer any of their operations activities of third-party organizations over the past decade grew more than in and a half time. So, the volume of outsourcing relations in the world economy today exceed $\$ 100$ billion of this volume more than $55 \%$ accounted for the share of the American continent, $45 \%$ - the share of Europe, and only 3\% - the share of the Asia-Pacific region.

\footnotetext{
* Corresponding author: natasha.chepkina@mail.ru
} 
The financial outsourcing sector covers $33 \%$ of all contracts and accounts for $26 \%$ of their total value, production sector- $17 \%$ and $15 \%$ respectively, telecommunications $-13 \%$ and $12 \%$, business services- $9 \%$ and $12 \%$, and other services- $9 \%$ and $5 \%$. According to a study by Industry Week Census on manufacturing, 54.9\% of American companies use outsourcing in production and $43.8 \%$ in equipment maintenance [1-3].

Housing-and-communal services reforming was endured in due time practically by all the countries of the world. The need of reforming of the industry is caused by certain conservatism of its structures and by the lack of internal stimulus to self-regulation. External factors (the consumers of housing-and-communal services) cannot always significantly influence the level and quality of these services. As the experience shows, housing-and-communal reforms are most successful and have no serious consequences, if carried out in the countries, where so-called middle class has the significant political status and a sort of leverage for the adoption of managerial decisions.

In Europe, there are three models of the housing-and-communal relations, one of which (English model) provides full privatization of the facilities of housing-and-communal utilities. Great Britain, where it became the main means of attraction of private means to the performance of municipal works became the first country, in which they began to apply outsourcing for the housing-and-communal utilities. In the German model, the housingand-communal enterprises turn into joint stock companies, but the controlling equity stake belongs to the municipalities. The French model combines a sole property on the facilities of housing-and-communal utilities with management of the private companies under longterm rent and the relevant investment contracts [4].

According to the trend, which exists in Europe today, in Poland, housing-andcommunal infrastructure, which owner is a local government was separated, and other institutions are engaged in providing services.

In Latvia, all housing-and-communal services were transferred to the possession of territorial communities. Therefore, there is no need for functioning of public authorities of housing-and-communal utilities. Each territorial community independently resolves the issues connected with the content of housing-and-communal services and its maintenance.

The analysis of domestic normative legal acts as well as the results of practical activities of local governments confirms the lack of the acquired complex actions for the increase in the efficiency of functioning of housing-and-communal utilities.

For the purpose of the activization of more effective use of outsourcing on utility companies it is necessary to hold some events: to improve the legislative base, which would protect the interests of domestic enterprise structures; to carry out explanatory work among the employees, concerning advantages of outsourcing; to provide a compensation package for the category of workers, who will be dismissed as the result of optimization of personnel processes; to carry out systematic monitoring of the market of outsourcing services; to diversify risks by selection of several providers.

\section{Methods}

The perspective actions of financial improvement and increase in the investment attractiveness of the enterprises of housing-and-communal services include attraction of own enterprise assets; attraction of budgetary funds, grants, loans; improvement of structure of business management and identification of internal reserves of the enterprise; resourcesaving by the means of introduction of economic levers and technical modernization of the enterprise.

The important lever is the allocation from the list of subjects of natural monopolies and transfer to their external specialized companies. Such approach is called outsourcing, it 
captured thousands of the companies of all industries and spheres of economy, in many countries of the world.

Outsourcing is a way of optimization of the activity of the enterprise by delegation of some tasks to the external specialized companies, which are professionally engaged in the solution of such tasks and focus on the main objectives and functions.

Some managers see the strategic importance of outsourcing for the business development first of all in the possibility of fast development with the implementation of new technologies, the solution of the problem of the absent or excess capacities; clearness in costs of the auxiliary processes, and, above all, the opportunities for professional to be engaged in business, but not its service.

In the world long ago, the issue about the basic need of outsourcing is not topical, its extreme importance is reliability and professionalism of partners with which the contract for performance of certain services is signed. This aspect forces the enterprise to answer some questions about the choice of the business processes transferred to outsourcing: what functions to transfer, how to organize decision-making process, how to estimate its effect and what evaluation criteria to use, which risks and possibilities of the use to expect.

The solution is the disposal of the unpromising and unprofitable directions of business and the conclusion of necessary, but non-core business processes to outsourcing. The essential part of the decision is made by the analysis of the efficiency of transfer to the external performer of a certain service.

According to the conducted research, the scheme of types of outsourcing with simultaneous isolation of the directions of application in the sphere of granting housingand-communal services is offered.

The general scheme of introduction of outsourcing in housing sector is presented in the fig. 1 .

\begin{tabular}{|c|c|c|}
\hline & Types of outsourcing & \\
\hline \multirow[b]{2}{*}{ Productive outsourcing } & $\downarrow$ & \\
\hline & $\begin{array}{c}\text { Business processes } \\
\text { outsourcing }\end{array}$ & IT - outsourcing \\
\hline I & I & T \\
\hline $\begin{array}{l}\text { Transfer to the private } \\
\text { companies: } \\
\text { - management and service } \\
\text { of buildings and territories; } \\
\text { - gardening of territories; } \\
\text { - repair of roads; } \\
\text { - garbage removal, etc. }\end{array}$ & $\begin{array}{l}\text { Transfer of separate, not } \\
\text { main business processes to } \\
\text { third parties: } \\
\text { - development of } \\
\text { scientifically based tariffs; } \\
\text { - human resource } \\
\text { management; } \\
\text { - accounting. }\end{array}$ & $\begin{array}{l}\text { Transfer of processes on } \\
\text { charge, collecting payments, } \\
\text { information exchange with } \\
\text { consumers of the communal } \\
\text { services; } \\
\text { - operation and service of } \\
\text { the automated system of } \\
\text { calculations. }\end{array}$ \\
\hline
\end{tabular}

Fig. 1. Introduction of outsourcing in the housing-and-communal sector.

However, there are also disadvantages of the use of outsourcing for management of housing-and-communal services, which are connected with certain risks [5-10].

Advantages, disadvantages and risks of application of outsourcing in housing-and communal-services are presented in Table 1. 
Table 1. Advantages, disadvantages and risks of application of outsourcing in housing-andcommunal utilities

\begin{tabular}{|c|c|}
\hline Advantages & Risks and disadvantages \\
\hline Concentration on one kind of activity & $\begin{array}{l}\text { Loss of control over the transferred } \\
\text { functions }\end{array}$ \\
\hline $\begin{array}{l}\text { Access to the resources and funds which are } \\
\text { unavailable (professional staff, financial, } \\
\text { information resources, business assets) }\end{array}$ & Outflow of information \\
\hline $\begin{array}{c}\text { Decrease in cost of the functions, transferred on } \\
\text { outsourcing }\end{array}$ & $\begin{array}{c}\text { Decline in quality in case of dishonesty of the } \\
\text { outsourcer }\end{array}$ \\
\hline Risk reduction due to collective investments & $\begin{array}{l}\text { Possibility of bankruptcy of the outsourcing } \\
\text { company }\end{array}$ \\
\hline Improvement of quality & $\begin{array}{l}\text { Training and growth of own workers is } \\
\text { limited }\end{array}$ \\
\hline $\begin{array}{l}\text { Absence of the need to have available } \\
\text { mobilization assets, to invest }\end{array}$ & Use of outdated technologies by the supplier \\
\hline in secondary directions of activity & Possibility of corruption conspiracy \\
\hline $\begin{array}{l}\text { Use of others experience and "algorithms" of } \\
\text { the solution of problems }\end{array}$ & $\begin{array}{c}\text { Discontent of the personnel transferred to } \\
\text { third party }\end{array}$ \\
\hline $\begin{array}{l}\text { The dependence on the subjective reasons of } \\
\text { suspension of business processes is minimized } \\
\text { (disease of employees, conflict) }\end{array}$ & Complication of deliveries \\
\hline $\begin{array}{l}\text { As the volume of knowledge and qualification } \\
\text { of each specific expert are limited, using } \\
\text { outsourcing, it is possible to attract "collective" } \\
\text { intelligence }\end{array}$ & Dependence on partners \\
\hline
\end{tabular}

The economic feasibility of the use of outsourcing as an important reserve of business in the sphere of housing-and-communal services is obvious.

The need for acquisition and preservation of competitive positions demands the expansion of limits of independence of the housing-and-communal enterprises, the increase in the responsibility for the end results, establishment of direct dependence of level of income from the efficiency of work, the need of creation of the model of management, adequate to the crisis fluctuations of the market.

Such approach provides reforming of mechanisms of functioning of the housing-and-communal enterprise, improvement of organizational forms and economic methods of providing it with material and other resources, that can be solved with the use of the corresponding tools of outsourcing [11].

The most popular directions of outsourcing in the sphere of housing-and-communal utilities are recruiting (personnel outsourcing), management of deliveries and logistics, maintenance of IT processes. It considerably expands the possibilities of utility companies, allows increasing income, creates conditions for commercial activity of participants of the investment complex and, eventually, it leads to the maximum satisfaction of a client.

\section{Results}

The analysis of the foreign experience of rather effective functioning of the housing-and-communal enterprises showed the lack of ready models of reforming of the industry, the importance of implementation of monitoring of all the transformations, as well as the need of the development of own strategy reforming of the industry taking into account some specifics at the present stage of the development of national economy.

Scientists determine the importance of timely use of outsourcing strategy taking into account the specifics of housing and communal business. In practice, it has the following advantages: concentration of the enterprise on the main activity; increase of organizational flexibility and quality 
of non-core business tasks; efficiency in decision-making; innovative methods in work; increase of investment attractiveness; division of risks between the customer and the outsourcing company; reduction or absence of costs for the maintenance and training of own staff of specialists; possibility of remote cooperation. crisis situation significantly increases the value of these benefits.

Thus, the analysis of the results of work of the bodies of housing-and-communal services in the foreign countries confirms the active role of the state and municipalities in the effective regulation of the housing sphere of the infrastructure directed to the creation of conditions of appearance of the interested participants of such market and fixing of the base of transparent and high-quality provision of services in this area.

In the enterprise environment of the country, there is a judgment of outsourcing which is an effective way of cost reduction, access to the latest technologies and the opportunity to concentrate on conducting primary activity. Despite some disadvantages and restrictions, outsourcing allows providing cost saving, high quality, release of resources for concentration on the main direction of business. For introduction of this new strategy for the housing-and-communal industry, it is necessary to consider not only the trends in world practice, but also the difficulty of transition to outsourcing, backwardness of the market, the imperfection of the legislation and the low culture of the contractual relations characteristic of the domestic enterprise environment. Advantages, which are revealed by the strategy of outsourcing, can cause the growth of economy in the nearest future in case of its careful study.

\section{Conclusions}

The research showed the importance of the formation and implementation of effective policy in the sphere of housing-and-communal services for the population. The importance of reorganization of the system of the housing-and-communal organizations and the possibility of the involvement of non-state small enterprises to the provision of services in housing sector is proved.

Foreign experience on the development of housing-and-communal services can be in the long term applied in the modern conditions of domestic public administration.

The complex use of instruments of effective management of management companies by state bodies, search and attraction of additional investments for modernization of housing stock in the future will give positive growth for the industry.

The implementation of outsourcing in the housing and utilities business should take into account the need for support efficiency of domestic producers in the conditions of economic transformation. This area has not been studied enough, but scientists and practitioners are working on the economic content of this concept and the development of methods for quantifying the effectiveness of outsourcing in housing and communal services. Aspect expediency and efficiency of outsourcing services in housing and communal services is most fully investigated in the works dedicated to assessing the effectiveness of the commercial system outsourcing using indicators of market stability and social and business activity of market turnover participants [12]. It is shown that problems of improvement of outsourcing in housing and communal services can be solved with the use of the concept development of a commercial outsourcing system using marketing tools, logistics, directions of controlling, and the creation of organizational and economic mechanism of outsourcing, which allows influencing the efficiency of business activities in the field of housing and communal services. The basis for achieving effectiveness should be marketing research to justify the complex services required by the construction organization in order to transfer part of them to outsourcing; as well as the creation of an organizational management mechanism of the commercial outsourcing system with the allocation of the logistics system, coordinates material, information and financial flows. This approach allows solving the problem of assessing the economic feasibility of outsourcing utilities. Practice shows that in the business environment of the country, there is an understanding that outsourcing is an effective way to reduce costs, access to the latest technologies and the ability to concentrate on the management core business. Despite some shortcomings and limitations, outsourcing can provide cost reduction, high quality, release of resources to focus on the main business direction. 
Implementation of this new strategy for the development of the industry should take into account not only the usual difficulties in the world of outsourcing, but also the underdevelopment of the market, the imperfection of the legislation and the weak culture of contractual relations characteristic of the domestic business environment. The advantages that the outsourcing strategy reveals with its careful study can cause its growth in the near future.

Summing up the results, it is possible to draw the conclusion, that functioning of housingand-communal services on the basis of introduction of outsourcing, is the priority direction. The criteria of determination of economic feasibility of outsourcing can be the ratio of own expenses on the performance of works of a certain type to the cost of works of the outsourcer. As the service companies in the modern conditions try to reduce expenses for the increase in efficiency of the activity, it is possible to recommend outsourcing for the purpose of formation of favorable investment climate in the housing-and-communal branch and for demonopolization of the market of housing-and-communal services.

\section{References}

1. T. Feng, Z. J. Ren, F. Zhang, Production and Operations Management, 28(3), 682-699 (2019) doi.org/10.1111/poms.12949

2. F. Law, European Management Journal Volume 36(3), 341-352 (2018) doi.org/10.1016/j.emj.2017.05.004

3. D. Mullins, T. Moore, International Journal of Housing Policy, 18(1), 114 (2018) doi.org/10.1080/19491247.2018.1422320

4. Loertscher, Simon, Michael H. Riordan, American Economic Journal: Microeconomics, 11 (1), 105-23 (2019) DOI: 10.1257/mic.20160347

5. D. Beimborn, N. Joachim, T. Weitzel, Betriebswirtsch, 82 (2012) doi.org/10.1007/s11573-012-0583-y

6. A. Yakhlef, Strategic Outsourcing: An International Journal, 2, 37-53, (2009) doi.org/10.1108/17538290910935882

7. B. K. Ray, S. Tao, A.Olkhovets, et al. EURO J Decis Process 1, 187, (2013) doi.org/10.1007/s40070-013-0013-6

8. L. Gaspareniene, J. Vasauskaite, Procedia - Social and Behavioral Sciences, 156, 274-279 (2014) doi.org/10.1016/j.sbspro.2014.11.188

9. J. Fountain, S. Langar, Automation in Construction, 95, 107-117 (2018) doi.org/10.1016/j.autcon.2018.06.009

10. K. Chen, H. Zhao, T. Xiao, Computers \& Industrial Engineering, 130, 127-141 (2019) doi.org/10.1016/j.cie.2019.02.010

11. A. Vaxevanou, N. Konstantopoulos, Procedia - Social and Behavioral Sciences, 175, 567-571 (2015)

12. L. Bals, V. Turkulainen, Journal of Purchasing and Supply Management, 23, 256-267 (2017) doi.org/10.1016/j.pursup.2017.06.003 
